\title{
RAIL RATES AND THE AVAILABILITY OF WATER TRANSPORTATION: THE MISSOURI VALLEY REGION
}

\author{
Mark L. Burton*
}

\begin{abstract}
Prior to deregulation, there was no clear relationship between the availability of water transportation and railroad rates. The Interstate Commerce Commission established maximum rates, so that railroads could not readily respond to changes in demand conditions. Any change in the management of navigable waterways stood only to affect the direct users-the shippers and barge operators. However, in the wake of the Staggers Rail Act, rail rates are more sensitive to both intramodal and intermodal competition so that any interruption or improvement in the availability of barge transport may now affect rail customers as well. Using the ICC's annual Carload Waybill Sample, this study examines railroad rates in the Missouri River Basin. The results point to water-compelled railroad rates for the movement of some commodities-in particular farm products. However, other bulk commodities appear to move under railroad rates that are independent from the influence of barge transportation.
\end{abstract}

\section{INTRODUCTION}

Prior to railroad deregulation in 1980 , there could be no assumption of a direct link between rail rates and the availability or appropriateness of alternative modes of transport. In theory at least, rail rates were established by the Interstate Commerce Commission based on the cost of service so that railroads could not easily respond to changes in demand conditions. In the wake of deregulation, this is no longer the case. The Staggers Rail Act brought rail carriers the freedom to establish virtually any rate that a particular market might bear. ${ }^{1}$ To the extent that deregulated rail carriers are interested in maximizing profits, it is now in their interest to be both aware of and sensitive to the transportation alternatives of shippers as they establish railroad rates. Consequently, any federal action that substantially affects the availability or pricing of water or highway transportation now has the potential to affect railroad rates as well. This newly formed relationship between rail rates and federal governance of other transport modes materially alters the potential effects of a wide range of transportation policy alternatives. In the following sections, I explore this new relationship by focusing on the federal control and support of navigation on the Missouri River. Specifically, I examine the way in which the water releases from the upper Missouri may affect rail rates for the movement of bulk commodities in and out of the Missouri River basin.

\footnotetext{
*Lafayette College, Easton, Pennsylvania. I would like to thank John W. Mayo and James MacDonald for their helpful comments and also to acknowledge the comments of two helpful referees.
} 
Section II provides a description of this river system. In Section III, I develop a model of railroad pricing behavior. Data and estimation techniques are discussed in Section IV. Section V presents an analysis of the empirical results, and Section VI contains some concluding remarks.

\section{THE MISSOURI RIVER SYSTEM AND COMMERCIAL NAVIGATION}

The Missouri River system of six dams is operated by the U.S. Army Corps of Engineers in response to regional demands for flood control, hydroelectric power, navigation, municipal and industrial water supply, fish and wildlife protection, and recreation. Strong competition for these water resources has severely taxed the ability of the main-stem system to meet these demands. Among the range of alternatives under review by the Corps of Engineers are those that would reduce support for commercial navigation. However, any revision in policy that mandates a reduction in the release of water from the upper reaches of the Missouri will almost certainly make barge operations more costly, and a serious interruption in flows could end commercial navigation on the Missouri altogether. ${ }^{2}$

Any assessment of the costs stemming from a closure of the Missouri to navigation must, among other things, define the group of shippers that would be affected. If a permanent end to navigation would affect only the shippers who currently use the Missouri River, then the economic costs to these shippers could be readily estimated. Table 1 summarizes barge traffic on the Missouri River in 1988. All told, only a little more than two million tons of primarily agriculturalrelated commodities were transported by barge on the Missouri. Given this modest level of traffic and the fact that barge rates are only pennies per ton-mile less than rates for other transport modes, the total value of additional transportation costs attributable to a Missouri River closure would seem negligible. However, if reduced support for Missouri River navigation also reduces competition within and between remaining modes of transportation, the cost owing to such a policy could be much greater as shown below.

\section{RAIL CARRIER BEHAVIOR, DATA, AND ESTIMATION}

For the purpose of this analysis, railroads are assumed to establish rates for groups of shippers based on observable characteristics rather than on the generally unobserved demands of individual shippers. These groups are defined by the origin and destination of the shipment and the two-digit Standard Transportation 
TABLE 1

1988 Missouri River Traffic Summary

\begin{tabular}{|c|c|}
\hline \multirow{2}{*}{\multicolumn{2}{|c|}{$\frac{\text { Commodity }}{\text { AGRICULTURAL }}$}} \\
\hline & \\
\hline Corn ..... & $\ldots \ldots \ldots \ldots 155$ \\
\hline Oats ..... & \\
\hline Sorghum & .93 \\
\hline Wheat . & 190 \\
\hline Soybeans . & .250 \\
\hline Animal feeds & . . . . 69 \\
\hline Grain mill . & $\cdots \cdot \frac{34}{799}$ \\
\hline
\end{tabular}

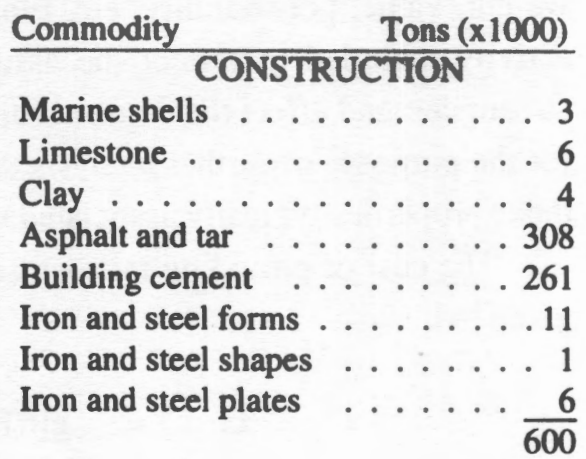

Commodity FERTILZER

Sodium hydroxide . . . . . . 13

Nitrogenous fertilizer . . . 213

Potassic fertilizer ...... 3

Phosphatic fertilizer . . . . . 34

Fertilizer . . . . . . 281

Basic chemicals ...... 8

Natural fertilizer ...... $\frac{1}{553}$

Commodity Tons (x1000) MANUFACTURING

Manganese ore $\ldots \ldots \ldots 1$

Ferroalloys ......... 7

Iron and steel prod. . . . . . 13

Machinery ......... 4

Scrap ............ 4

Coke ............ $\frac{18}{47}$
Commodity PROCESS AGRICULTURE

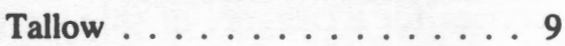

Molasses .......... 40

Vegetable oils .......... $\frac{25}{74}$

\begin{tabular}{cc} 
Commodity & Tons (x1000) \\
\hline OTHER
\end{tabular}

Alcohols and antifreeze ..... 13

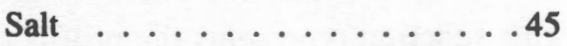

Newsprint ........... $\frac{5}{63}$

Total traffic ....... 2, 2,

(All Commodities)

Source: U.S. Army Corps of Engineers

Commodity Code (STCC) so that carriers establish rates for shipments of commodity " $k$ " between origin " $\mathrm{i}$ " and destination "j." The demand for transportation services by each group of customers is specified as:

$$
Q_{i j k t}=\mathbf{f}(P, M, K, A)
$$

where $Q_{i j k}$ is the quantity of railroad transportation (measured in ton-miles) demanded in period "t." $\mathrm{P}$ is the own price offered by the rail carrier. $\mathbf{M}$ is a vec- 
tor of variables describing the availability and relative prices of rail and non-rail transportation substitutes, and $\mathbf{K}$ is a set of commodity characteristics such as weight, value, perishability, etc. Finally, A is a measure of aggregate economic activity included to reflect the assumption that cyclical fluctuations in downstream demand affect the demand for transportation services. It is simply assumed for the purposes of further analysis that this function is well behaved and exhibits those properties typically associated with market demand functions.

The cost of providing railroad services to the various groups of customers is given by:

$$
\mathrm{C} \quad=\quad \mathrm{g}[\mathrm{f}(\mathrm{P}, \mathbf{M}, \mathbf{K}, \mathrm{A}), \mathbf{S}, \mathbf{R}, \mathbf{F}]
$$

where $\mathrm{C}$ represents the total cost (in dollars) of producing some quantity of rail services for a category of shipper. $\mathbf{P}, \mathbf{M}, \mathbf{K}$, and $\mathbf{A}$ are as defined above. $\mathbf{S}$ is a vector of shipment characteristics including weight, distance, number of loads, special equipment requirements, etc. $\mathbf{R}$ denotes a set of route characteristics such as the number of line interchanges and the overall density of traffic along the route. Finally, $\mathbf{F}$ is a set of factor prices and productivity measures.

Combining equations (1) and (2) generates the profit function:

$\mathrm{p} \quad=\mathrm{f}(\mathrm{P}, \mathbf{M}, \mathbf{K}, \mathrm{A}) * \mathrm{P}-\mathrm{g}[\mathrm{f}(\mathrm{P}, \mathbf{M}, \mathbf{K}, \mathrm{A}), \mathbf{S}, \mathbf{R}, \mathbf{F}]$

This function represents the profits obtainable from the sale of transportation services to a distinct group of customers, which is again defined by the commodity and by the origin and destination of the shipment. Costs are assumed to be additive and separable during each time period so that the resulting prices and associated revenues from sales to each group are also independent. This does not imply that rail carriers ignore the effects of overall traffic density on the dispersion of common costs when setting rates. It does indicate, however, that these carriers may only consider the impact of past sales on traffic density in preceding periods. ${ }^{3}$

Equation (3) is assumed to be at least twice and continuously differentiable and strictly concave. These assumptions, combined with the implicit function theorem, allow for differentiation and solution for an own price function that, by concavity, is guaranteed to represent the profit-maximizing price, $\mathrm{P}^{*}$, where:

$$
\mathbf{P}^{*}=\mathbf{h}(\mathbf{M}, \mathbf{K}, \mathbf{A}, \mathbf{S}, \mathbf{R}, \mathbf{F})
$$


It is this equation that forms the basis for the empirical consideration of the link between available water transportation and railroad rates.

The principal source of data for this investigation is the Interstate Commerce Commission's annual Carload Waybill Sample (CWS) public use file for the years 1973 through 1987 excluding $1975 .{ }^{4}$ The expanded records for movements in or out of the Missouri River basin were aggregated by origin-destination pair, commodity, and quarter to reflect the assumption that carriers set prices based on easily identified shipper characteristics. This formulation yields a pooled cross section and time series data set where the shipments of a particular commodity are represented cross sectionally by a variety of state-to-state origin-destination pairs that are then pooled to form the quarterly time series. ${ }^{5}$

A reduced form equation driven by Equation (4) is estimated separately for each of seven (two-digit level) bulk commodities which might be appropriately transported by water. This method of analysis eliminates the necessity of including commodity characteristics in the estimation. Instead, inter-commodity comparisons may be made by comparing the values of the other coefficients for each of the commodities. The dependent variable in each estimation is defined as the revenue per ton-mile (RATE). The value of this variable is calculated from the line haul revenue, net tons, and mileage fields of the CWS. The values are then placed in real terms by use of the Implicit GNP deflator. ${ }^{6}$ Variables to proxy $\mathbf{M}$, $A, S$, and $\mathbf{R}$, as well as the variables designed to detect the impact of deregulation, are defined below.

A zero/one dummy variable, (WATER), is used to capture the availability of water transport between the origin and destination states, with a value of one indicating that water transport is viable. If carriers possess any degree of monopoly power, profit maximization implies rate differentials based on varying price elasticities. In such cases, one would expect a negative correlation between the availability of water transport and railroad rates for the movement of bulk commodities. $^{7}$

The bulk commodities for which rates are examined are low-valued goods that are not generally transported long distances by truck. Apart from water transport, the only other viable alternative for shippers is carriage by competing railroads. The variable (DIRSRV) is included as a measure of this intramodal competition. It is defined as the number of carriers offering service between the origin " $\mathrm{i}$ " and destination " $\mathrm{j}$ " in period " $\mathrm{t}$." In a perfectly competitive environment, this variable should have no impact on rates, but in any one of a variety of oligopoly settings, one would expect rates to decline as the number of firms increases. $^{8}$

The other independent variables included in the empirical specification are 
MNINT The mean number of interchanges for shipments of commodity " $k$ " between origin " $i$ " and destination " $j$ " in period " $t$." Holding all else equal, the number of interchanges increases the cost of service so that the sign of the coefficient for MNINT is expected to be positive.

MTONS The mean number of tons included in shipments of commodity " $k$ " between origin " $\mathrm{i}$ " and destination " $\mathrm{j}$ " in period " $\mathrm{t}$." Economies of scale in terminal and switching operations suggest that the value of the estimated coefficients for this variable will likely be negative.

MMILES The mean number of miles for shipments of commodity "k" between origin " $\mathrm{i}$ " and destination " $\mathrm{j}$ " in period " $\mathrm{t}$." Assuming relatively fixed terminal costs and line-haul costs, which are linear in terms of distance, one might expect the coefficient for MMILES to be less than zero.

MMILES2 The square of MMILES. Again, assuming that terminal charges are fixed and that average line-haul costs are constant, the coefficient for this variable is expected to be positive.

DENSITY The total volume of traffic between origin " $i$ " and destination " $\mathrm{j}$ " in period "t." Braeutigam et al. (1984) suggest that any real economies in rail shipping are the result of density, not scale. Accordingly, railroad costs (and rates) might be expected to decline until some minimum efficient density is attained. Beyond this optimal level, DENSITY may have no impact or may even appear positive.

AVPROD The simple mean of the quarterly index of manufacturing production for periods " $t$ " and "t-1." Ignoring the possibility of mode switching, it is hypothesized that transport demand becomes less elastic during periods of accelerated economic activity so that the sign of the estimated coefficients for AVPROD is expected to be positive.

TIME Cross-sectional variations in factor productivity and factor prices are assumed to be minimal. However, there have been and continue to be improvements in the general technology available to rail carriers. The intertemporal impact of these improvements is captured by the trend variable TIME. All else being equal, one would expect coefficient estimates for this variable to be negative. 
The above may be combined to obtain:

$$
\begin{aligned}
\text { RATE }_{\mathrm{ijt}}= & \beta_{0}+\beta_{1}\left(\text { MNINT }_{\mathrm{ijt}}\right)+\beta_{2}\left(\text { MTONS }_{\mathrm{ijt}}\right)+ \\
& \beta_{3}\left(\text { MMILES }_{\mathrm{ijt}}\right)+\beta_{4}\left(\text { MMILES }_{\mathrm{ijt}}\right)+\beta_{5}\left(\text { DIRSRV }_{\mathrm{ijt}}\right)+ \\
& \beta_{6}\left(\text { DENSITY }_{\mathrm{ijt}}\right)+\beta_{7}\left(\text { WATER }_{\mathrm{ijt}}\right)+\beta_{8}\left(\text { AVPROD }_{\mathrm{ijt}}\right)+ \\
& \beta_{9}\left(\text { TIME }+\epsilon_{\mathrm{ijt}}\right.
\end{aligned}
$$

which explains rail rates in the absence of any regulatory change.

To account for the impact of deregulation on rates, the estimation contains an intercept variable (STAGG) and a set of interaction variables defined as the product of STAGG with the right-hand-side variables in Equation (5a). STAGG takes on a value of zero for each year prior to 1981 and a value of one multiplied by the years since the passage of Staggers for all years thereafter. ${ }^{9}$ The interaction terms carry the original variable name preceded by the letter "S," of Staggers. The final model to be fitted for each commodity is then:

$$
\begin{aligned}
& \text { RATE }_{\mathrm{ijt}}=\beta_{0}+b_{1}\left(\text { MNINT }_{\mathrm{ijt}}\right)+\beta_{2}\left(\text { MTONS }_{\mathrm{ijt}}\right)+ \\
& \beta_{3}\left(\text { MMILES }_{\mathrm{ijt}}\right)+\beta_{4}\left(\text { MMILES }_{\mathrm{ijt}}\right)+\beta_{5}\left(\text { DIRSRV }_{\mathrm{ijt}}\right)+\beta_{6}\left(\text { DENSITY }_{\mathrm{ijt}}\right)+ \\
& \beta_{7}\left(\text { WATER }_{\mathrm{ijt}}\right)+\beta_{8}\left(\text { AVPROD }_{\mathrm{ijt}}\right)+\beta_{9}\left(\text { STAGG }_{\mathrm{ijt}}\right)+\beta_{10}\left(\text { SMNINT }_{\mathrm{ijt}}\right)+ \\
& \beta_{11}\left(\text { SMTONS }_{\mathrm{ijt}}\right)+\beta_{12}\left(\text { SMMILES }_{\mathrm{ijt}}\right)+\beta_{13}\left(\text { SMMILES2 }_{\mathrm{ijt}}\right)+ \\
& \beta_{14}\left(\text { SDIRSRV }_{i j t}\right)+\beta_{15}\left(\text { SDENSITY }_{i j t}\right)+\beta 1_{6}\left(\text { SWATER }_{\mathrm{ijt}}\right)+ \\
& \beta_{17}(\text { SAVPROD } i j t)+\beta_{18}(\text { TIME })+\epsilon \mathrm{ijt}
\end{aligned}
$$

where the combination "ij" represents a specific origin-destination pair for some time period "t."

The flexibility of this specification provides three benefits. First, one can explore the impact of WATER and the other independent variables on rail rates during the regulated era by examining the coefficient estimates for $\beta_{0}$ through $\beta_{8}$. Second, the value for STAGG, when combined with the slope interaction variables, depicts the way in which deregulation changed carriers' responses to the independent variables. It is the sum of the coefficient for the interaction term with its corresponding variable coefficient that indicates carriers' present propensity toward the independent variable. Finally, by setting the value of WATER to zero, one can predict the rates that might have been charged in the absence of available water transport and compare these predictions to the observed rates for the various commodities.

Based on the outcomes of previously conducted tests, the original estimation technique corrected for autocorrelation and heteroskedasticity. The disturbance 
for each origin-destination pair $\epsilon_{\mathrm{ijt}}$ was found to be serially correlated with the disturbance for the same routing in period " $t-1$." The model also accounted for differing disturbances across origin-destination pairs within any particular period. A comparison of the results from this Estimated-Generalized-Least-Squares (EGLS) estimation technique, and those yielded by ordinary least squares, revealed no substantive differences in coefficient values. At the same time, the ordinary least squares estimates are much more useful in the preparation of predicted values. Therefore, it is this latter set of estimation results that are reported by this analysis.

\section{WATER COMPETITION AND DEREGULATED RAIL RATES}

A full set of regression results describing the estimation of Equation (5b) for seven bulk commodities is available as a statistical appendix to this paper. Coefficient estimates and significance levels for WATER and SWATER are reported below in Table 2. In general, these results are consistent with those of Burton (1992) and MacDonald (1987, 1989a). Table 2 suggests that the water alternative acts to lower rates in all three of the cases where the sums of WATER and SWATER are statistically significant.

The effect of deregulation on the relationship between available water transport and rail rates appears negligible. Rail rates that were sensitive to the presence of a water alternative in the wake of Staggers displayed this same tendency before its implementation. There are, at least, two possible explanations for this observation. First, it is possible that the regulation of rates for the movement of these commodities was ineffectual or non-binding. This explanation supposes that rail carriers were able to manipulate the regulatory process in order to obtain the set of prices responsive to various demand conditions. This interpretation might be embraced by those who viewed the pre-Staggers Interstate Commerce Commission as little more than a vehicle by which cartel behavior was monitored and enforced. Alternatively, it is possible that, prior to deregulation, the ICC imposed differential rates that favored shippers with better access to inland water transport for the Commission's own purposes and that rail carriers simply chose to maintain this pattern after deregulation. ${ }^{10}$

To capture the magnitudes by which railroad rates might change if the water alternative were eliminated, the analysis employs a two-step process. First, the estimated coefficients are used to predict values based on the observed values of the independent variables. Next, using the same coefficients and the same values for the independent variables except WATER, I generate a second set of predicted values. However, whereas WATER equaled either zero or one in the first predic- 
TABLE 2

Effects of Available Water Transport

\begin{tabular}{|c|c|c|c|c|c|c|}
\hline Commodity & Variable & Coefficient & Test Sta* & Prob. & $\begin{array}{c}\text { Predicted } \\
\text { Ton/Mile } \\
\text { Rate } \\
\end{array}$ & $\begin{array}{l}\text { Impact of } \\
\text { Navigation } \\
\text { Alternative }\end{array}$ \\
\hline Food & WATER & -0.007091749 & -2.455 & 0.0142 & \multirow[t]{3}{*}{$\$ 0.171$} & \multirow[t]{3}{*}{$-29.04 \%$} \\
\hline \multirow[t]{2}{*}{ Products } & SWATER & 0.000158504 & 0.168 & 0.8669 & & \\
\hline & SUM & -0.0069332 & 8.2599 & 0.0041 & & \\
\hline \multirow[t]{3}{*}{ Coal } & WATER & 0.01752799 & 2.457 & 0.0143 & \multirow[t]{3}{*}{$\$ 0.0374$} & \multirow{3}{*}{$\begin{array}{l}\text { No statistical } \\
\text { significance }\end{array}$} \\
\hline & SWATER & 0.000098130 & 0.042 & 0.9663 & & \\
\hline & SUM & 0.01761 & 0.1209 & 0.7282 & & \\
\hline \multirow{3}{*}{$\begin{array}{l}\text { Metallic } \\
\text { Ore }\end{array}$} & WATER & 0.003363975 & 1.111 & 0.2673 & \multirow[t]{3}{*}{$\$ 0.045$} & \multirow{3}{*}{$\begin{array}{l}\text { No statistical } \\
\text { significance }\end{array}$} \\
\hline & SWATER & 0.000945069 & 0.732 & 0.4647 & & \\
\hline & SUM & 0.004309 & 0.7288 & 0.3939 & & \\
\hline \multirow{3}{*}{$\begin{array}{l}\text { Non-Metallic } \\
\text { Minerals }\end{array}$} & WATER & -0.006836056 & -1.725 & 0.0848 & \multirow[t]{3}{*}{$\$ 0.039$} & \multirow[t]{3}{*}{$-17.02 \%$} \\
\hline & SWATER & 0.001197419 & 0.690 & 0.4902 & & \\
\hline & SUM & -0.0056386 & 2.8603 & 0.0911 & & \\
\hline \multirow[t]{3}{*}{ Chemicals } & WATER & -0.000540735 & -0.551 & 0.5816 & \multirow[t]{3}{*}{$\$ 0.0426$} & \multirow{3}{*}{$\begin{array}{l}\text { No statistical } \\
\text { significance }\end{array}$} \\
\hline & SWATER & 0.000121494 & 0.356 & 0.7216 & & \\
\hline & SUM & -0.0004192 & 0.7409 & 0.3869 & & \\
\hline \multirow[t]{3}{*}{ CCG\&S** } & WATER & -0.005060382 & -2.798 & 0.0052 & \multirow[t]{3}{*}{$\$ 0.0349$} & \multirow[t]{3}{*}{$\cdot 12.75 \%$} \\
\hline & SWATER & -0.000263847 & -0.359 & 0.7193 & & \\
\hline & SUM & -0.005324 & 3.3354 & 0.0683 & & \\
\hline \multirow{3}{*}{$\begin{array}{l}\text { Scrap } \\
\text { Material }\end{array}$} & WATER & 0.002551541 & 1.168 & 0.2430 & \multirow[t]{3}{*}{$\$ 0.0510$} & \multirow{3}{*}{$\begin{array}{l}\text { No statistical } \\
\text { significance }\end{array}$} \\
\hline & SWATER & -0.000953444 & -1.245 & 0.2131 & & \\
\hline & SUM & 0.0015981 & 0.8125 & 0.3675 & & \\
\hline
\end{tabular}

" $\mathrm{t}^{\mathrm{n}}$ statistics are reported for individual coefficients. " $\mathrm{F}$ statistics, indicating a test for joint significance, are reported for all sums.

**Clay, Concrete, Glass, and Stone

tions, it is set to zero for all observations when generating the second set of predicted values. The difference between these two predicted values provides some measure of the potential impact if support of commercial navigation on the Missouri should be withdrawn. The predictions are summarized and discussed for each of the seven commodities.

\section{Farm Product Shipments}

A re-examination of Table 1 suggests that grain shipments are a significant fraction of the total traffic currently moving on the Missouri. However, the public-use portion of the CWS consistently provides only a two-digit Standard Transportation Commodity Code (STCC) designation for shipments. Therefore, 
the analysis considers the broader commodity definition known as "farm products." Still, it should be noted that the vast majority of all farm product shipments in and out of this region are shipments of grains. For this reason, one may prudently assume that these results most generally reflect the good that dominates this commodity class.

The results of the analysis of rates for the movements of farm products are generally consistent with those of MacDonald (1989b). Even though there is little grain on the Missouri at this time, the simple presence of the water alternative is dampening rail carriers' ability to capture larger profits. The CWS data indicate that an average shipment of farm products toward a Gulf port moved at a rate of $\$ 12.41$ per ton in $1987 .{ }^{11}$ In the absence of barge movements along the Missouri, shippers would have likely paid $\$ 17.50$ per ton. That is, the per-ton-mile rate was estimated to rise from $\$ 0.0171$ to $\$ 0.0241$ when the water alternative is removed.

The difference between rail rates that were observed in 1987 and the rates that could have been charged in the absence of a water alternative may, in fact, be somewhat understated by the above estimates. The estimated rate of $\$ 17.50$ per ton cited above, while higher than the observed rates, is substantially below the rate shippers pay to truck grain from the Missouri River Valley to river ports on the Mississippi for barge shipment to the Gulf. This truck-barge rate represents a limit price above which rail carriers could not charge without risking serious loss of traffic. The gap between the $\$ 17.50$ rate and the truck-barge rate (estimated by the Tennessee Valley Authority to be approximately $\$ 26.00$ per ton) largely reflects the degree of intramodal rivalry that currently exists between rail carriers.

The analysis of the extent to which reduced support of navigation on the Missouri may affect rail rates was based on the simplifying assumption that the volume of railroad traffic would not be appreciably altered by such a reduction. In fact, it is possible that the volume of farm products shipped by rail from the region may be somewhat affected. ${ }^{12}$ Using 1985 traffic levels, Burton (1991) estimates that, in the most extreme case, the volume of farm products moving to the Gulf would fall from $\mathbf{4 4 . 3}$ million tons per year to 39.7 million tons per year in response to heightened railroad rates.

This last point brings up a difficult but important question. Precisely what volume of railroad grain movements can policymakers expect to move under rates that would be made higher by the elimination of the water alternative? Many of the roughly 45 million tons of grain produced and shipped from the Missouri River basin each year are grown at locations too distant from the nearest water terminal for water to be a viable alternative. Beyond what distance does water cease to affect railroad rates, and how much of the grain grown within the region lies within the potentially affected area? 
While the data do not support the empirical investigation that could fully resolve these questions, some inference based on other studies is nonetheless possible. First MacDonald (1987) found that available water transport sharply dampens railroad rates, but that this type of relationship deteriorates as the water alternative becomes more remote. He analyzed the relationship for wheat, corn, and soybean shipments and found that the availability of water transport is an important determinant of rate for all three. In the case of wheat, MacDonald notes that rail rates were 40 percent higher when the origin was at a distance of 400 miles from the nearest port than they were for shipments that originated 100 miles or less from available water. Further, the realization that, in most cases, grain must be trucked to the port provides another clue as to the efficacy of water competition. Many of the costs (primarily terminal costs) of trucking are invariant to shipment distance. Still, most analyses suggest that motor carriers cannot compete with railroads for the movement of grain once the shipment distance extends to between 300 and 500 miles (see Pitman 1988). Rail-barge combinations are certainly possible. Nonetheless, the high cost of truck transport would seem to limit the potential impact of available water transport. Consequently, it seems reasonable to believe that the possibility of a barge alternative significantly affects rates for the movement of grain up to a distance of around 100 miles, but that these effects are generally exhausted when the shipper is $300-400$ miles from the nearest port.

\section{Coal Movements}

Historically, coal has not been an important commodity on the Missouri River even though it would seem to be a likely candidate for barge transport. In fact, in 1989, only 11 barges loaded with coal moved on the Missouri. The majority of coal movements in and through the region have their origin in the Powder River Basin of Wyoming and Montana, from which an all water routing is impossible. ${ }^{13}$ Further, the volume of Powder River coal that moves eastward is expected to expand significantly over the next decade. ${ }^{14}$ Not only do most coal shipments have an origin that is not served by barge, but the extreme density of western coal traffic and the rivalry between western railroads have led to low rail rates. Thus, shipments into the Missouri River basin from other coal-producing regions for which water might be a feasible alternative are dominated by inexpensive Powder River coal. The data suggest that, if anything, the availability of water transport increases rail rates for the movement of coal, but again, this result owes to the extremely low rates for coal movements out of the Powder River Basin where no water alternative is available. ${ }^{15}$ 


\section{Metallic Ore and Non-Metallic Minerals}

The model did not offer a particularly good fit for the collection of goods that fall into the category of metallic ore. A preliminary examination of the data suggests that there were fewer shipments within this category than there were for other goods. There is only limited mining of such commodities in the region, and there is not particularly heavy usage by downstream processors. The availability of water transport had no significant impact on rail rates either prior to or after the passage of Staggers. ${ }^{16}$

In contrast to the above, the availability of water transportation is an important determinant of the rates under which non-metallic minerals are shipped. The analysis suggests that goods in this category moved at an average of $\$ 0.039$ per ton-mile in 1987 when water transportation was available. Were it not for the water alternative, this rate might have been as much as $\$ 0.046$ per ton-mile, so that the threat of water transport saved shippers an average of $\$ 3.30$ per ton based on the mean shipment distance. This commodity grouping includes:

- Crushed or broken stone.

- Gravel or sand.

- Clay, ceramic, or refractory minerals.

- Chemicals or fertilizer minerals.

- Miscellaneous non-metallic minerals, n.e.c.

Some of the commodities are currently in evidence on the Missouri and most have, at least, some history of water shipment. It is particularly interesting that the raw materials which are the source for agricultural fertilizers are included in this group. This suggests that changes in the level of support for commercial navigation may affect the rail rates for the movement of agricultural inputs as well as rates for the movement of harvested farm products.

\section{Chemicals}

Again, the model fit for this group of commodities is not particularly good. This is likely due to the diverse set of characteristics inherent in these commodities. ${ }^{17}$ However, there is some reason to suspect that rail rates for agricultural chemicals are affected by the availability of a water alternative. Large volumes of such commodities move from processing facilities in Louisiana north to the Missouri basin in the late winter and early spring of each year. Since the same equipment is used to move agricultural chemicals and farm products, the only real cost of the chemical movements is the additional expense of towing 
loaded barges rather than empties. Survey data suggest that when the Mississippi was temporarily closed to navigation in 1990 , railroads significantly increased their rates for the movement of agricultural chemicals, so that low barge rates for the movements of these commodities certainly seem to dampen rail rates. ${ }^{18}$

\section{Concrete, Clay, Glass and Stone}

As in the case of non-metallic minerals, there is solid evidence suggesting that the presence of a water alternative has helped to dampen rates for the movement of commodities within this category. The analysis suggests that goods within this STCC moved at an average rate of $\$ 0.0349$ per ton-mile when barge transport was an available option. The elimination of this option would have brought an increase in the rates to $\$ 0.040$ per ton-mile.

\section{Scrap Materials}

If this analysis contains any inexplicable result, it is the lack of association between railroad rates for the movement of scrap and the availability of water transportation. Scrap (particularly scrap metal) is a non-trivial portion of all rail traffic, so it is difficult to imagine that carrier pricing is not sensitive to available water competition. The analysis indicates that rail rates for the movement of scrap are responsive to the number of rail carriers offering service and that this trend was significantly reinforced by deregulation, but the link between rail rates and water transport remained statistically weak.

\section{CONCLUDING REMARKS}

A reduction of upstream water releases on the Missouri River would have a variety of economic effects, some of which are related to a possible closure of the Missouri to navigation. To the extent that the federal government once fully controlled the two modes of transport that are used to move bulk commodities in and out of the region, this same government might have more closely controlled the consequences of an end to commercial navigation. However, in the absence of direct regulatory control of railroad rates and operating practices, regulators must anticipate that railroads will respond to substantial changes in the availability of water transport. This research suggests that the magnitude of such responses may not be trivial for some commodities, so that any failure to consider railroad response may lead to suboptimal policy decisions. 


\section{ENDNOTES}

1. Staggers did provide for residual regulation under which any rail rate that exceeds 180 percent of average variable cost is subject to regulatory review.

2. Current operating procedures attempt to maintain a nine-foot deep channel during an operating season that begins April 1 and ends December 1 of each year. Occasionally, drought conditions have necessitated a one-foot reduction in channel depths. This, in turn, forces a light loading of barges. Any reduction in releases from the upper Missouri that would bring channel depths to a level of less than eight feet would probably end commercial navigation altogether.

3. In any particular time period, railroads provide a diverse set of outputs through the utilization of largely common facilities. The price that a rail carrier charges one set of customers presumably affects the quantity of goods that those shippers move by rail and the total quantity of traffic over which common cost may be spread. In this way, the profit maximizing price for one distinct set of customers is inexorably tied to those prices charged to other classes of customers. The result is that profit maximizing behavior would require the solution of a simultaneous system containing one equation for each set of customers. Such a system is tractable for neither rail carriers nor for economists attempting to model carrier behavior. For a further discussion of this issue, see Wilson (1993).

4. ALK Associates, the firm which distributes the Carload Waybill Sample, is unable to produce a public use tape for 1975. Additional data were obtained from the Association of American Railroad's Yearbook of Railroad Facts and the Official Railway Guide.

5. There has been some controversy surrounding the revenues reported in the CWS for the years since 1981 due to the existence of contract rates that are allowed under Staggers. Contracts between carriers and shippers often involve quantity-based rebates or penalties. Carriers are not required to report these rebates or penalties as a part of the billed rate. Further, there is nothing on the waybill to indicate that a contract was in force. Some, such as Professor Boyer, have argued that the possible corruption of the line haul revenue field of the CWS makes this sample unusable. Others, including MacDonald $(1987,1989 \mathrm{a})$ and Winston, Corsi, Grim, and Evans (1990) have demonstrated that reasonable use of the sample is still possible.

6. During the course of various revisions to this research, a number of different price indexes were substituted in place of the GNP deflator. These alternative indexes produced no substantive change in results.

7. In the case of farm products, the definition of WATER is a bit more restrictive. For these commodities, water is considered a viable option only when the shipment is destined for a Gulf port. Other studies (MacDonald 1989a; Burton 
1993) have used a distance-to-water variable to denote the availability of water transportation. The geographic peculiarities of the Missouri River Basin thwarted my attempts to replicate this methodology here. However, attempts to better represent the presence of navigable waterways continues.

8. The distribution of traffic between carriers who serve a particular route may be as important as the number of such carriers in determining the degree of extant competition. Unfortunately, the data do not allow a carrier-by-carrier breakdown of traffic so that a more elegant measure of intramodal rivalry is not possible. This notwithstanding, Bresnahan and Reiss (1990) suggest there is often a strong discontinuity in the effect of the number of incumbent rivals. This latter issue, as it applies to surface freight transport, certainly deserves additional attention.

9. Initially, the deregulation variable was specified as a zero-one dummy variable. Over the course of subsequent revisions, I experimented with a number of appropriate alternative specifications and noted only the most modest difference in results.

10. Burton (1993) found that, prior to deregulation, rail rates for a broad range of commodities were made lower by the presence of water transportation even when some of these commodities would not be appropriately moved by barge. His explanation for this observation and for the subsequent changes brought by deregulation lies in the pattern of "equalizing discrimination" identified by Boyer (1981). Boyer demonstrates that, during the regulated era, the ICC often set rail rates in order to equalize the positions of more remote shippers. An examination of the structure of inland waterways suggest that this pattern of discrimination would have been highly correlated with the availability of water transport.

11. All rate figures have been deflated by use of the Producer Price Index and are reported in 1984 dollars.

12. On the one hand, the grain currently moving by barge might be added to the volume moving by rail. Conversely, it is possible that higher rail rates to Gulf destinations might divert some amount of export traffic to non-Gulf destinations or stop some movements altogether.

13. Some western coal is railed to the Mississippi, where it is transloaded to barges for continued shipment. However, these intermodal shipments typically do not involve movement on the Missouri because the Missouri has a shorter navigation season, more unreliable flows, smaller tow sizes, and lighter loadings.

14. In 1990, 169 of the total 254 million tons of low-sulphur coal billed originated in the Powder River region. This volume is expected to increase significantly due to the passage of the 1990 Clean Air Act. Western rail carriers are so confident of increased coal traffic that they are investing millions to accom- 
modate the additional movements. For example, Union Pacific plans to spend $\$ 250$ million before 1995 to improve its trackage from western Nebraska to Kansas City.

15. An attempt to validate this hypothesis by including a dummy variable indicating a Powder River origin was unsuccessful, in part because of the small number of coal shipments with alternative origins.

16. Conversations with railroad management have revealed that there is often some minimum level of traffic below which railroads will not actively compete with each other or with alternative modes, as if the total profits available from the commodity simply do not warrant their concern.

17. This STCC includes everything from bulky agricultural fertilizers to high valued pressurized gases.

18. This information comes from an unpublished Tennessee Valley Authority survey of Missouri River shippers.

\section{REFERENCES}

Boyer, Kenneth. "Equalizing Discrimination and Cartel Pricing in Transport Rate Regulation." Journal of Political Economy 89, no. 2 (April 1981): 270-286. Braeutigam, Ronald R., Andrew F. Daugherty, and Mark A. Turnquist. "A FirmSpecific Analysis of Economies of Density in the U.S. Railroad Industry." Journal of Industrial Economics 33 (September 1984): 408-416.

Bresnahan, Timothy F., and Peter C. Reiss. "Entry and Competition in Concentrated Markets." Journal of Political Economy 99, no. 5 (1991): 9771009.

Burton, Mark L. "Rail Rates and the Availability of Water Transportation: The Missouri Valley Region." Center for Business and Economic Research, University of Tennessee, September 1991.

. "Railroad Deregulation Carrier Behavior and Shipper Response: A Disaggregated Analysis." Journal of Regulatory Economics (December 1993).

Garrod, Peter V., and Walter Miklius. "Captive Shippers' and the Success of Railroads in Capturing Monopoly Rent." Journal of Law and Economics 30, no. 2 (October 1987): 423-433.

McDonald, James. "Competition and Rail Rates for the Shipment of Corn, Soybeans, and Wheat." Rand Journal of Economics 18, no. 1 (Spring 1987): 151-163. 
. "Railroad Deregulation, Innovation, and Competitive Effects of the Staggers Act on Grain Transportation." Journal of Law and Economics 32, no. 1 (April 1989): 63-96.

- Effects of Railroad Deregulation on Grain Transportation. U.S. Department of Agriculture, Technical Bulletin No. 1759, 1990.

Pitman, Russell. "Railroads and Competition: Why the Santa Fe/Southern Pacific Merger Had to Die." U.S. Department of Justice, Economic Analysis Group, Washington, D.C., 1988.

Wilson, Wesley W. "Commodity-Specific Effects of Rail Deregulation." Journal of Industrial Economics (December 1993).

Winston, Clifford, Thomas M. Corsi, Curtis M. Grim and Carol A. Evans. The Economic Effects of Surface Freight Deregulation. Washington, D.C.: Brookings Institute, 1990. 